\title{
Resurgence of Harrisia portoricensis (Cactaceae) on Desecheo Island after the removal of invasive vertebrates: management implications
}

\author{
Cielo E. Figuerola-Hernández ${ }^{1, *}$, Kirsty Swinnerton ${ }^{1,2}{ }^{,}$Nick D. Holmes ${ }^{1}$, \\ Omar A. Monsegur-Rivera ${ }^{3}$, José Luis Herrera-Giraldo ${ }^{1}$, Coral Wolf ${ }^{1,4}$, \\ Chad Hanson ${ }^{1}$, Susan Silander ${ }^{5}$, Donald A. Croll ${ }^{4}$ \\ ${ }^{1}$ Island Conservation, Santa Cruz, California 95060, USA \\ ${ }^{2}$ The Island Endemics Foundation, Boquerón 00622, Puerto Rico \\ ${ }^{3}$ Caribbean Ecological Services Field Office, US Fish and Wildlife Service, Boquerón 00622, Puerto Rico \\ ${ }^{4}$ Coastal Conservation Action Lab, University of California Santa Cruz, Santa Cruz, California 95060, USA \\ ${ }^{5}$ Caribbean National Wildlife Refuge Complex, US Fish and Wildlife Service, Boquerón 00622, Puerto Rico
}

\begin{abstract}
Desecheo Island hosts a natural population of the higo chumbo cactus Harrisia portoricensis, listed as threatened under the US Endangered Species Act. The species was extirpated from mainland Puerto Rico and is restricted to the offshore islands of Mona, Monito and Desecheo. Herbivory by goats Capra hircus, rhesus macaques Macaca mulatta, and black rats Rattus rattus introduced to Desecheo Island have likely contributed to a population decline, with only a few individuals of higo chumbo reported in 2003. As part of a restoration program, goats have been eradicated, macaques are considered functionally extirpated, and actions to remove invasive rodents were completed in 2016 and confirmed as successful in 2017. Systematic monitoring was implemented between 2010 and 2013, including widespread searches for $H$. portoricensis, collecting data on population structure, number of individuals, height, number of branches and evidence of phenological events. After $4 \mathrm{yr}$ of continuous monitoring, 72 individual plants were identified, which exhibited increased height and branching throughout the study years. No seedlings were observed and only a few juveniles recorded, suggesting a resurgence from suppressed adults with limited recruitment. Long-term monitoring is critical to understanding the population dynamics of this species on Desecheo Island. Efforts to safeguard this species on the island require completion of the invasive vertebrate removals and would benefit from a seed banking program and manual establishment of new populations.
\end{abstract}

KEY WORDS: Invasive species - Eradication - Threatened species - Caribbean · Herbivory · Harrisia portoricensis $\cdot$ Cactaceae $\cdot$ Desecheo Island

\section{INTRODUCTION}

Islands represent key areas for biodiversity conservation due to high levels of species endemism (Myers et al. 2000). Invasive species have been identified as a leading cause of extinctions (Tershy et al. 2015), and remain a primary threat to extant island biodiversity (Wege et al. 2010). Insular flora face threats from invasive herbivores and omnivores that de-

${ }^{*}$ Corresponding author:

cielo.figuerola@islandconservation.org crease plant diversity, alter plant community structure, accelerate soil erosion, and aid seed dispersal of exotic plants (Sussman \& Tattersall 1981, Walter \& Gillett 1998, Simberloff \& Von Holle 1999, Rojas-Sandoval et al. 2014). The Caribbean is home to approximately 11000 plant species, of which $72 \%$ are endemic to the region (Anadón-Irizarry et al. 2012). Within these, the Cactaceae family is one of the most vulnerable and ecologically important in the Carib-

(1) C.E.F.-H., K.S., N.D.H., J.L.H.-G., C.W., C.H., D.A.C. and, outside the USA, the US Government 2017. Open Access under Creative Commons by Attribution Licence. Use, distribution and reproduction are unrestricted. Authors and original publication must be credited. Publisher: Inter-Research · www.int-res.com 
bean (Fleming \& Valiente-Banuet 2002), containing a large number of endangered and threatened species (Walter \& Gillett 1998, Ortega-Baes \& Godínez-Álvarez 2006). Threats include disturbance (Godínez-Álvarez et al. 2003), illegal collection and trade (Casas et al. 2002, Zimmermann \& Pérez-Sandi 2006), habitat loss, diseases and invasive species (USFWS 1996).

The higo chumbo Harrisia portoricensis is a columnar cactus endemic to Puerto Rico and known only from the offshore islands of Mona, Monito, and Desecheo, west of Puerto Rico (USFWS 1996). The species has been extirpated from the main island of Puerto Rico, and in 1990 it was listed as threatened under the US Endangered Species Act, and considered Endangered under the 1997 IUCN Red List of Threatened Plants (Walter \& Gillett 1998). Identified threats include natural catastrophes like hurricanes, habitat modification, low genetic variation, and herbivory by invasive species on Mona and Desecheo islands (USFWS 1996). On Desecheo Island, rhesus macaques Macaca mulatta were introduced in 1966 (Evans 1989) and goats Capra hircus were introduced through several undocumented events (Breckon et al. 1998, Meléndez-Ackerman et al. 2008). Black rats Rattus rattus were introduced with the arrival of the first Europeans into the region in the 15th century (Woodbury et al. 1971). A total of 161 plant species have been documented on Desecheo, and 59 of the total species were extirpated between 1915 and 1997 (Breckon 2000). The higo chumbo may have evolved in the presence of (now extinct) native browsers, but was susceptible to intense herbivory and frugivory pressures exerted by introduced non-native goats, macaques, and rats. Macaques have previously been identified as detrimental to $H$. portoricensis, with individuals observed breaking off and eating young stems (Noble \& Meier 1989, Breckon 2000). Debris from cactus foraging by macaques and goats was reported by Evans (1989), including the consumption of $H$. portoricensis fruits by macaques. Goats and macaques were observed feeding on the moist pulp after heavy rains, suggesting this was an important water source in the xeric climate on Desecheo (Evans 1989). In addition to these negative impacts, macaques may have had a positive role as seed dispersers of $H$. portoricensis (e.g. Sengupta et al. 2014); however this is unclear. Black rat consumption of $H$. portoricensis is unknown but should not be ruled out, given this species is highly omnivorous, and fruit, seeds, and vegetative matter from plants constitute a frequent component of their diet (Shiels et al. 2013). However, seed consumption by $R$. rattus when non-native on islands is generally a negative relationship (seed pre- dation) as many seeds do not survive gut passage (Shiels et al. 2013). Breckon \& Kolterman (1994) estimated approximately 430 adult and 120 juvenile $H$. portoricensis in 1994; the presence of different sized individuals indicated that reproduction and recruitment were occurring. Subsequent observations have suggested a dramatic decline, with 5 individuals recorded in 1999 (Santiago-Vélez 2000) and 9 in 2003 (Schwagerl pers. comm., cited in USFWS 2010), representing 0.9 to $1.6 \%$ of the observations made in 1994 .

Conservation actions on Desecheo have included removal of macaques, goats, and rats. Attempts to remove the macaques were initiated in 1977 (Evans 1989) with focused efforts between 1985 and 1987, and more recently since 2009. As of December 2013, the population was considered functionally extinct, i.e. reproduction ceased with only one wild macaque known to remain on the island, and as of 2017, the project was declared successful (Hanson et al. in press). Goat removal was initiated in 1976, with most individuals removed between 1998 and 2003 (USFWS unpubl. data); the last individuals were removed in 2009 (C. Hanson pers. obs.). In total, at least 642 goats and 295 macaques were removed (Evans 1989, USFWS unpubl. data, Hanson in press). Rat eradication has been attempted twice: a failed attempt in 2012, and a second, successful attempt in 2016. The removal of the herbivory pressure exerted by these invasive species is expected to benefit native plant populations, including $H$. portoricensis (USFWS 2011).

Point and baseline surveys for the higo chumbo were conducted in 2003 and 2009, respectively, but no individuals were found (Island Conservation 2009), although detection probability for seedlings and juveniles could have been low due to their small size (0 to $50 \mathrm{~cm}$ ). Systematic monitoring was subsequently implemented from 2010 to 2013 and data on population structure, architecture of individuals, and evidence of phenological events were recorded. Here, we provide an updated report on the status of the population of $H$. portoricensis on Desecheo Island following removal of invasive vertebrates, and make recommendations for the management of the species.

\section{MATERIALS AND METHODS}

\section{Study site}

Desecheo is a small, mountainous island of 122 ha $\left(18^{\circ} 23^{\prime} \mathrm{N}, 67^{\circ} 29^{\prime} \mathrm{W}\right)$ approximately $21 \mathrm{~km}$ west of Punta Higüero, Puerto Rico. Maximum elevation is $213 \mathrm{~m}$ (Morrison \& Menzel 1972), and vegetation is a 
mosaic of grassy patches, shrublands, and woodlands with candelabra cacti and semi-deciduous forest (Woodbury et al. 1971). Annual rainfall on Desecheo is 750 to $1039 \mathrm{~mm}$ (Morrison \& Menzel 1972, Seiders et al. 1972), with a dry period from January to March and a high rainfall period between July and October. Farming activities occurred in the 1920s (Struthers 1927), and the island was used by the US Air Force as a bombing, gunnery, and survival training site until 1964. In addition to goats and macaques, invasive black rats Rattus rattus are also present. This island was transferred to the US Fish and Wildlife Service to be managed as a National Wildlife Refuge (NWR) in 1976. It is closed to the public due to safety concerns as well as to protect the resources of the island; however, limited recreational activities occur offshore including snorkeling and diving.

\section{Study species}

Harrisia portoricensis or higo chumbo, is a slender, upright, columnar cactus, endemic to Puerto Rico, belonging to the family Cactaceae, subfamily Cactoideae, tribe Trichocereeae. This genus comprises 18 species, all of them endemic to their region of origin and with restricted ranges. Fourteen of these species are restricted to the Caribbean region and 4 are restricted to the southeastern part of South America (Argentina, Bolivia, and Paraguay; Anderson 2001). Juvenile plants are usually unbranched, whereas adults may reach heights of more than 2 to $3 \mathrm{~m}$ and are usually extensively branched (Liogier 1994). Although there is no information on the age of first reproduction for $H$. portoricensis in Puerto Rico, observations from local botanists state it can start producing flowers after 8 to $10 \mathrm{yr}$ (O. A. Monsegur-Rivera pers. obs.). Other species in this genus start producing flowers after 3 to $5 \mathrm{yr}$, when the stems are 600 to $900 \mathrm{~mm}$ long (Auld \& Medd 1992). The cactus is night-flowering with hermaphroditic flowers that are whitish, fragrant, and showy. Plants are iteroparous and may produce flowers multiple times within a year (Santiago-Vélez 2000). Studies in 2010 found the species exhibits a partially self-compatible breeding system, reproducing sexually through a wind-aided self-pollination mechanism (Rojas-Sandoval 2010); however, due to floral characteristics, its pollination system could have been different in the past. It is possible that this system may have lost the more effective pollinators (e.g. bats, insects or birds) due to natural disturbances (i.e. hurricanes), or through impacts from invasive alien species (Aslan et al. 2012), and it may now be relying on alternative mechanisms for pollination (Rojas-Sandoval 2010). On Mona Island, for example, pollinators are known to include the hawkmoth species Pseudosphinx tetrio (Sphingidae). Mature fruits are yellow, spineless berries with more than 1500 small black seeds embedded in a white pulp (Liogier 1994). The main dispersal agents include native birds, lizards, water, and wind (O. A. Monsegur-Rivera pers. obs.). However, there is no genetic variability at the individual, population, or species level in $H$. portoricensis, although given its life history traits and geographic limitations this is to be expected (Santiago-Vélez 2000). There is no specific information on the lifespan of $H$. portoricensis but it is estimated these cacti can live for several decades (O. A. Monsegur-Rivera pers. obs.).

\section{Data collection}

Systematic surveys and monitoring occurred between June 2010 and June 2013, with one monitoring visit per year conducted between March and June. All accessible areas on the island were searched and known individuals revisited (found from 2011 to 2013). Areas covered included the West Valley and the Long Valley (western side), the Hog's Back (northern side), the East Point (eastern side) and all of the southeastern and southern slopes of the island. Two persons spent on average $7 \mathrm{~d}$ each year conducting the surveys, investing an average of $8 \mathrm{~h} \mathrm{~d}^{-1}$. All individuals were marked with a metal tag on a wire around the base of each plant and GPS coordinates were recorded.

\section{Plant structure}

We considered juvenile plants as those measuring $50 \mathrm{~cm}$ or less in height, and adults as $51 \mathrm{~cm}$ or more. For each individual encountered we measured the height of the stalks from base to tip, or from the lowest point on the plant to tip, counted the number of branches, and described key characteristics including number of stalks, flowers, fruits, and extensive disease or browsing. We tabulated the number of branches (including buds) that juveniles and adults exhibited as an indicator of mechanical damage (i.e. breakage of a branch or stalk) at that stage, since a high degree of branching could be evidence of herbivory during early life stages because the loss of apical dominance results in the activation of lateral buds 
which will develop into branches (Dun et al. 2006). We visualized the relationship between height and number of branches in a scatterplot (see Fig. 2).

Photos

We took at least 2 standardized, north-facing photos of each individual at $1 \mathrm{~m}$ distance from the plant. Additional close-up photos of the plant, scars, markings, flowers, or other items of interest were recorded as well.

\section{Growth rate}

We calculated the mean growth rate and mean number of emergent branches per year in all cases where we had 4 yr of consecutive data. Growth was quantified as the increase in total plant length measured for plants from one survey to the next.

\section{Analyses}

Analyses of branch number against height of cactus were undertaken using Pearson's correlation coefficient, and conducted in Minitab v.14.0. Distribution was mapped using a geographic information system (GIS; ArcGIS v.10.1) and overlaid with the historical 1994 distribution (Breckon \& Kolterman 1994). Differences between years for growth rate and number of branches were calculated with a repeated measures ANOVA.

\section{RESULTS}

During our 4 yr study period (2010 to 2013), we found and measured a total of 72 individuals of Harrisia portoricensis (Table 1). Approximately $85 \%$ were found within the study area of Breckon \& Kolterman (1994) (Fig. 1), and $90 \%$ of individuals in the area of sparse vegetation and bare land on the east slopes of the island. Values for height and number of branches increased consistently from 2010, with an increase of $16 \%$ from 2010 to 2011 , $50 \%$ from 2011 to 2012 , and $33 \%$ from 2012 to 2013.
Table 1. Mean $( \pm \mathrm{SD})$ number of individuals observed, height, and number of branches per year for Harrisia portoricensis measured on Desecheo Island. $\mathrm{n}=$ number of individuals from which we calculated the means and for which we had 3 or more years of data

\begin{tabular}{|ccccc|}
\hline Year & $\begin{array}{c}\text { Total } \\
\text { individuals } \\
\text { observed }\end{array}$ & $\begin{array}{c}\text { Mean } \\
\text { height } \\
(\mathrm{cm})\end{array}$ & $\begin{array}{c}\text { Mean no. } \\
\text { of branches } \\
(\mathrm{cm})\end{array}$ & $\mathrm{n}$ \\
\hline 2010 & 31 & $64.7 \pm 30.5$ & $0.41 \pm 0.75$ & 27 \\
2011 & 36 & $93.9 \pm 49.1$ & $0.90 \pm 1.07$ & 19 \\
2012 & 54 & $119.8 \pm 47.3$ & $1.25 \pm 1.73$ & 41 \\
2013 & 72 & $145.2 \pm 55.3$ & $2.83 \pm 3.75$ & 38 \\
\hline
\end{tabular}

We also calculated the mean growth rate and mean number of emergent branches per year for 18 individuals for which we had 4 consecutive years of data (Table 2). Growth rate decreased each year, more abruptly between the first and second year (2010 to 2011). The number of emergent branches per year was comparable in the first $2 \mathrm{yr}$ but increased in the final year. We found significant differences between the $3 \mathrm{yr}$ of study for mean growth rate $\left(F_{2,34}=17.552\right.$, $\mathrm{p}<0.05)$ and for mean number of branches $\left(F_{3,51}=\right.$ $24.525, \mathrm{p}<0.05)$. Between 2010 and 2011, 33\% of observed individuals were juveniles. This decreased to $3 \%$ (2 individuals) during 2012 and 2013. From 13 observations of juveniles ranging from 12 to $50 \mathrm{~cm}$ in height, we found 12 presented branching, with 1 individual exhibiting 15 branches $(r=0.305, \mathrm{p}=0.31)$

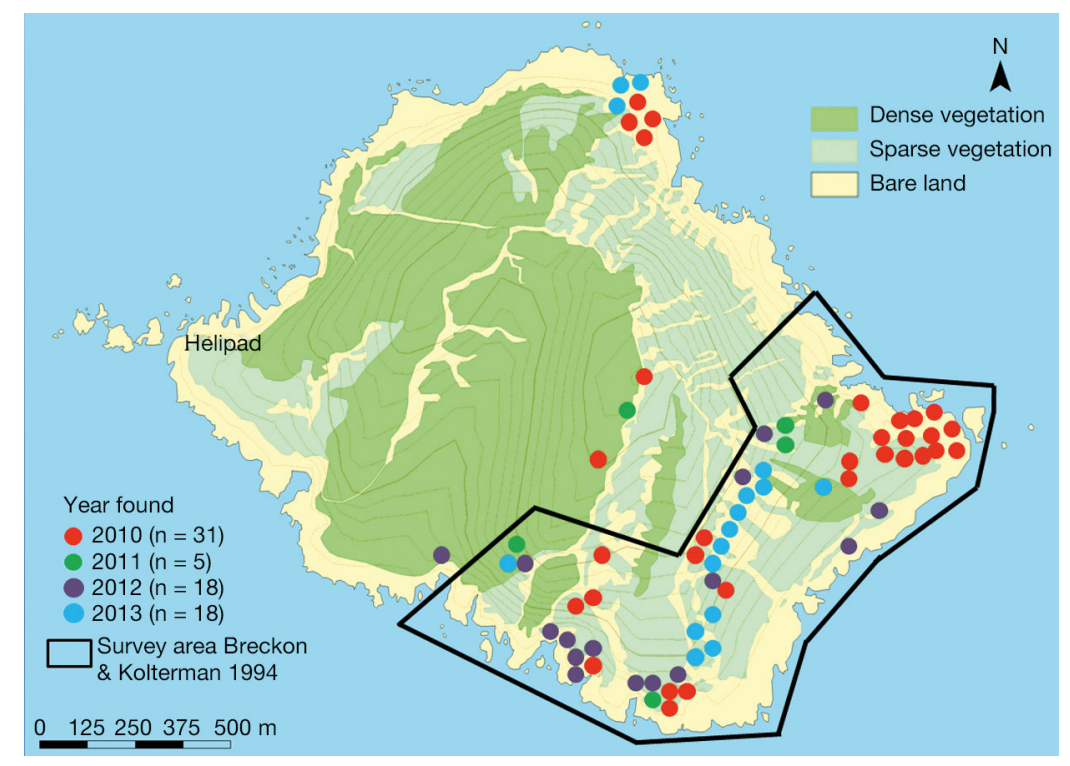

Fig. 1. Distribution of Harrisia portoricensis in 1994 (Breckon \& Kolterman 1994) and from 2010 to 2013 on Desecheo Island, Puerto Rico. New individuals found every year are presented as the $\mathrm{n}$ for each year. (Desecheo vegetation map credit: P. Minton, EVS Islands) 
Table 2. Mean $( \pm \mathrm{SD})$ growth rate and emergent branches per year for a subset of the population of Harrisia portoricensis, June 2010 to June 2013 ( $\mathrm{n}=18$ )

\begin{tabular}{|lcc|}
\hline Year & $\begin{array}{c}\text { Mean growth } \\
\text { rate }\left(\mathrm{cm} \mathrm{yr}^{-1}\right)\end{array}$ & $\begin{array}{c}\text { Mean no. of } \\
\text { branches borne } \mathrm{yr}^{-1}\end{array}$ \\
\hline $2010-2011$ & $39.87 \pm 10.85$ & $0.49 \pm 0.86$ \\
$2011-2012$ & $26.44 \pm 7.26$ & $0.35 \pm 0.50$ \\
$2012-2013$ & $22.79 \pm 6.95$ & $1.58 \pm 1.93$ \\
\hline
\end{tabular}

(Fig. 2). A total of 4 fruiting events were observed on 4 individuals: 3 events with 4 fruits in 2012 and 1 event with 6 fruits in 2013 (Fig. 3). The maximum number of fruits observed on a single individual on Desecheo Island was 6 (Fig. 4A). No flowering events were observed (all fieldwork was conducted during the day); however, we encountered 11 individuals with closed flowers and flower buds (Fig. 4B).

\section{DISCUSSION}

Eradication of invasive species from islands is a commonly used tool to achieve biodiversity conservation goals (Jones et al. 2016). Monitoring outcomes for native flora and fauna is an important aspect of eradication projects to determine if these goals are being met, and to provide insights for planning of future projects (Bellingham et al. 2010). Our study provides an additional effort towards building a general framework for understanding vegetation out-

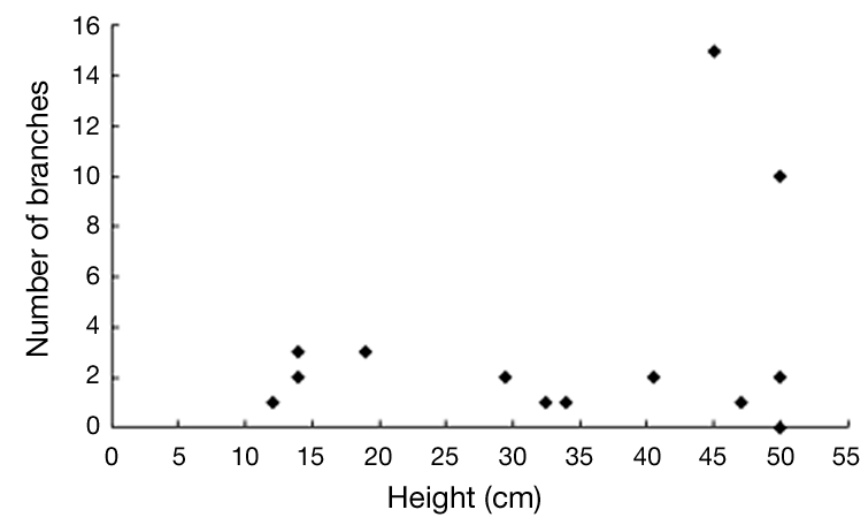

Fig. 2. Plant height and number of branches on juvenile Harrisia portoricensis, June 2010 to June $2013(r=0.305, p=0.31$ )

comes from invasive herbivore and omnivore removal (Schweizer et al. 2016). The increased number of higo chumbo individuals observed on Desecheo from 2010 to 2013 in relation to the removal of macaques and goats (Fig. 5) provides insight for understanding release from herbivory. In 2010 surveys, 22 individuals were located, and in each subsequent year of monitoring additional individuals were found. Total height of marked individuals increased every survey year (Table 1), with a recent trip to the island in 2016 reporting new seedlings growing in the vicinity of previously located adults (R. Albarracín pers. comm., C. E. Figuerola-Hernández pers. obs., J. García-Cancel pers comm.). Collectively, our results suggest that the population is resurging from suppressed adults due to the release from herbivory

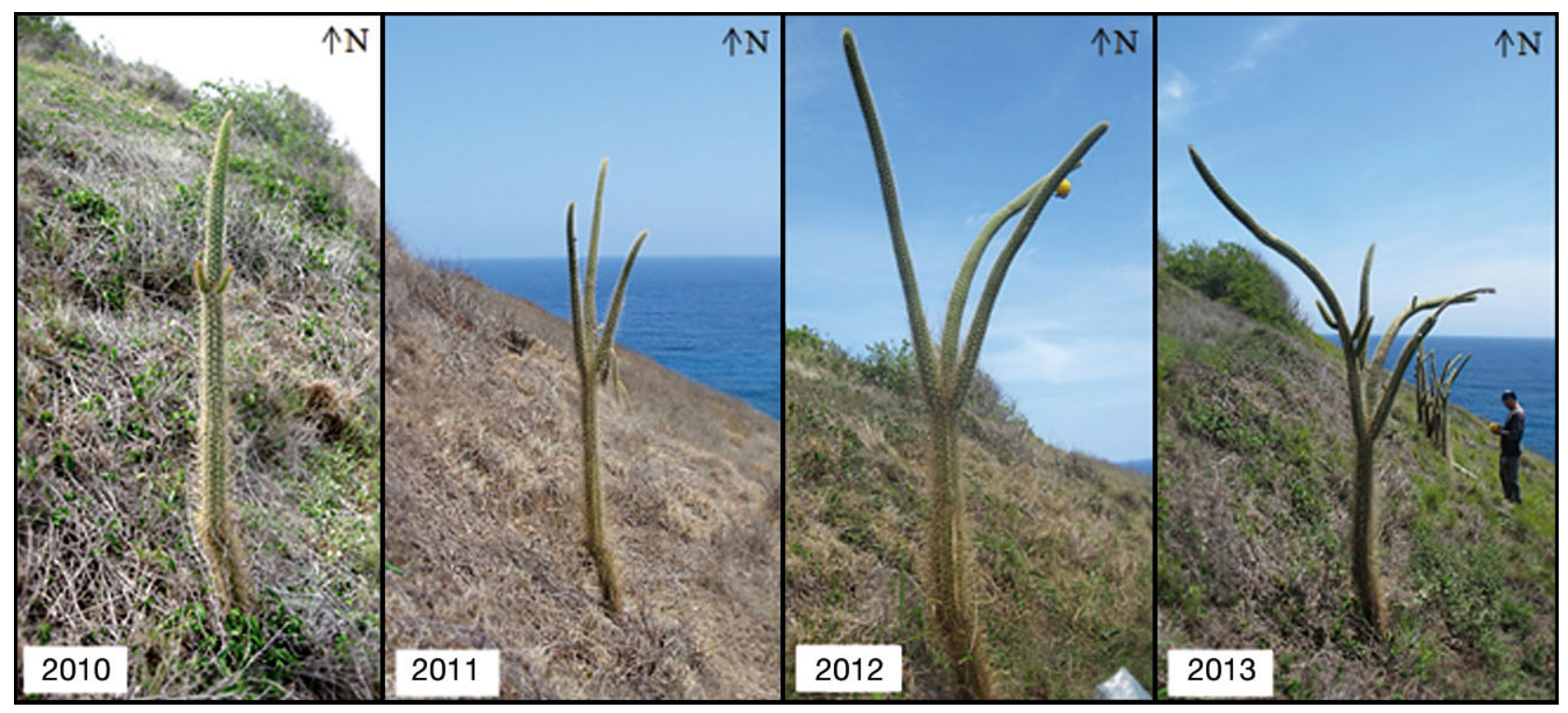

Fig. 3. Photographic sequence of the development of an Harrisia portoricensis individual from 2010 to 2013 . Note the presence of a fruit in 2012 and the significant branch development during the following year 


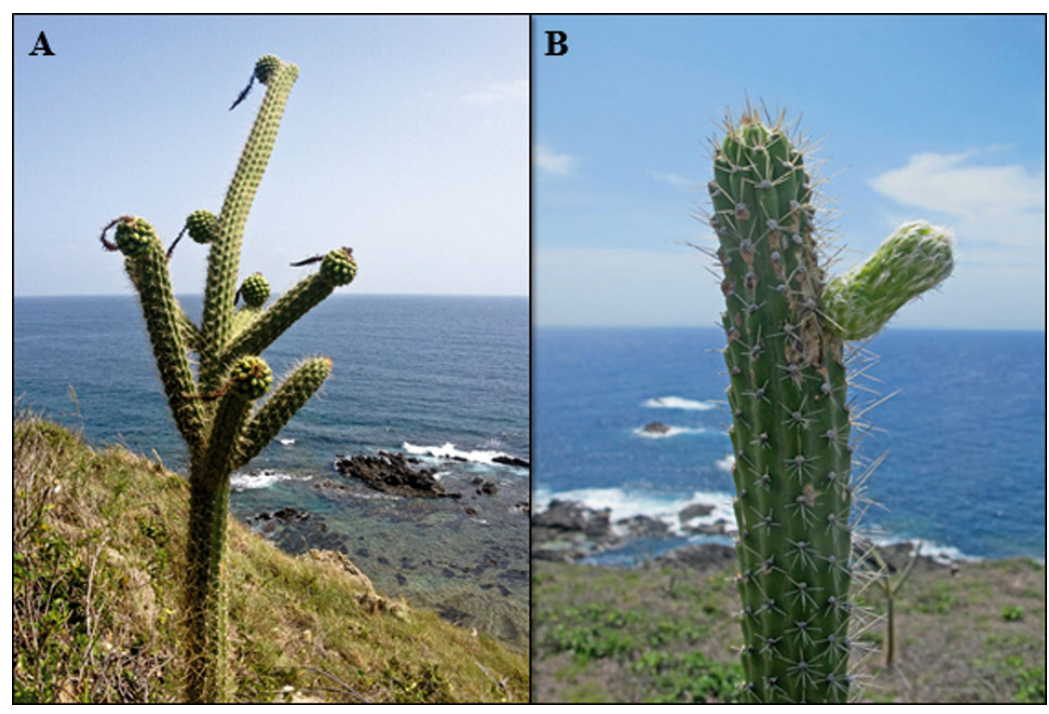

Fig. 4. Phenological events observed in Harrisia portoricensis on Desecheo Island: (A) 6 immature fruits on a single individual, and (B) flower buds in different stages of development on several of the individuals

impacts from goats and macaques. Although observations indicated that at the start of the study (2009) the primary herbivory pressure was from the large invasive macaque population, it is likely that goats were also important in suppressing recruitment and growth. Indeed, unpublished reports indicate that by the 1990s the vegetation of the island had been decimated and significant erosion was taking place due to goat herbivory. These results are consistent with studies elsewhere: cacti (Opuntia sp.) in the Galápagos showed strong recovery on islands with the removal of invasive goats (Hamann 1993, 2001).
The distribution of $H$. portoricensis on Desecheo island found in our study followed previous distribution patterns described in 1994 (Breckon \& Kolterman 1994), with $85 \%$ of the individuals located on the south and southeastern slopes of Desecheo (Fig. 2). These slopes are characterized by sparse vegetation composed mainly of cacti, shrubs, and grasses with wide patches of bare land. Groups of individuals mainly conglomerated in bare land areas (Fig. 2), since these areas offer more sun exposure and less competition for nutrients from other plants, especially during the early life stages when $H$. portoricensis seedlings are more vulnerable to these impacts. West-facing slopes on Desecheo Island maintain deeper soils, fostering a denser vegetation structure and less solar radiation, which is less conducive for $H$. portoricensis establishment. Due to footage from a network of camera traps, it is evident that invasive mammals moved throughout the whole island; therefore, it is unlikely their feeding behavior determined the distribution pattern of $H$. portoricensis. Distribution patterns are comparable on Mona Island, where the highest densities of higo chumbo are located on the dry shrubland and grassland areas, characterized by a greater percentage of rock cover and lower percentage of ground covered by leaf litter (Rojas-Sandoval 2010). We expect a fully

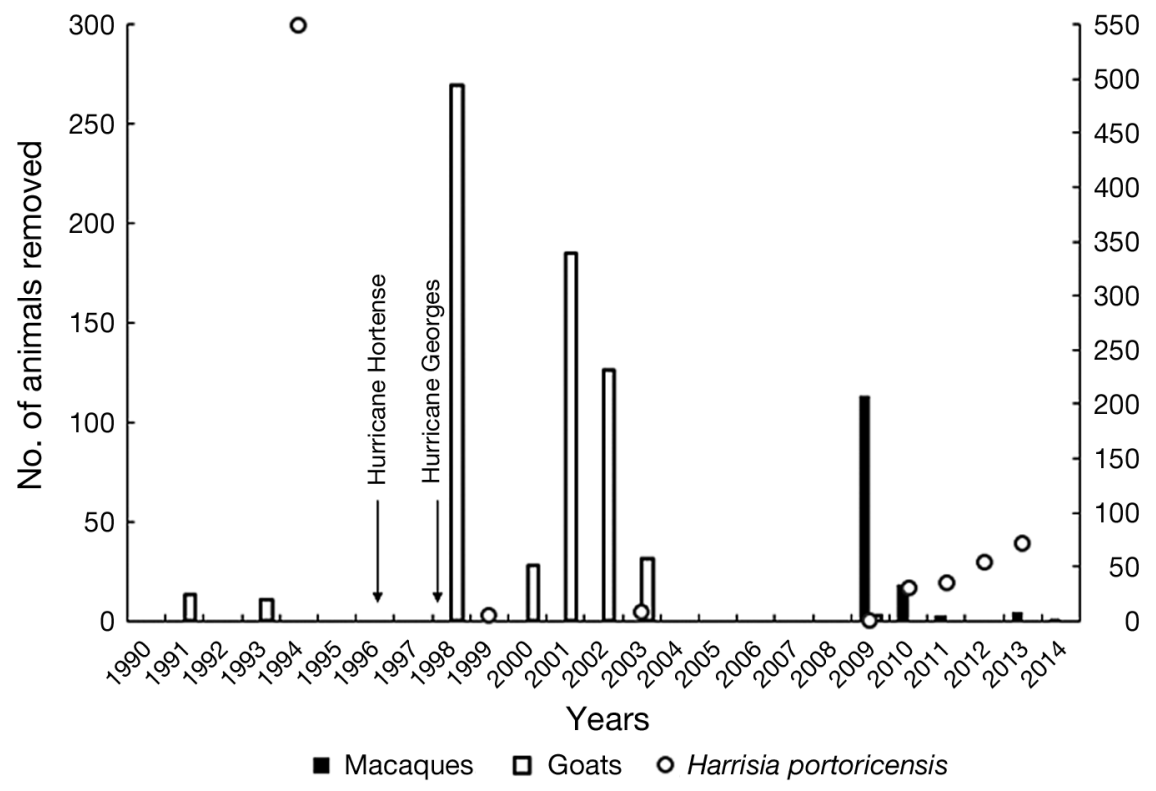

Fig. 5. Harrisia portoricensis found from 1994 to 2013 considering the number of goats and macaques removed from Desecheo Island during that time (USFWS unpubl. data, C. Hanson unpubl. data). Hurricane events are also noted. Years without data represent years in which no animals were removed 
recovered population of $H$. portoricensis on Desecheo Island will be mostly limited to the xeric-mesic habitat available on the south and southeastern slopes.

The higo chumbo typically requires at least $10 \mathrm{yr}$ to mature (O. A. Monsegur-Rivera pers. obs.), yet by 2013 , several individuals measured $>2 \mathrm{~m}$ and exhibited abundant branching and fruiting; characteristics typical of adult plants (Rojas-Sandoval 2010) (Table 1). We observed the fastest growth rate of higo chumbo in the first year of the study (Table 2), with growth rates varying between years. We believe this represents suppressed adults resurging from stored resources in the roots (Van Bloem et al. 2006). In general, among columnar cacti, taller individuals exhibit greater branching as a means to compensate for height and weight instability (O. A. Monsegur-Rivera pers. obs.). Many of the individuals we observed followed this pattern, with larger individuals having produced more branches; although we also observed smaller individuals with a high degree of branching, perhaps additional evidence of earlier herbivory. Cacti respond to mechanical damage to a branch or stalk by further branching; the loss of apical dominance results in the activation of lateral buds which will develop into branches (Dun et al. 2006). We observed 13 higo chumbos measuring $50 \mathrm{~cm}$ or less with between 0 and 15 branches.

While we observed a progressive increase in the total number of individuals across the years monitored, in later years the proportion of smaller size classes was reduced. Typically, this species has a low percentage $(7.2 \%)$ of seed germination under natural conditions even though individuals are able to fruit and flower throughout the year (Rojas-Sandoval 2010). For example, the demographic structure of $H$. portoricensis on Mona Island, where invasive pigs, goats, and rodents are present, included plants in the adult $(59 \%)$, juvenile $(34 \%)$, and seedling stages (7\%) (Rojas-Sandoval 2010), a pattern similar to that observed on Desecheo Island. Seedling growth could have been restricted by the presence of rodents at the time of the study - seed and seedling predation by invasive Rattus sp. has been documented elsewhere (Towns et al. 2006). Further, search efficacy on Desecheo Island improved as cacti grew to a conspicuous size and could be seen above the grass and shrub layers. Lastly, cacti recorded as juveniles during the first $2 \mathrm{yr}$ of the monitoring study after the removal of all goats (2009) may have in fact been established individuals with stunted growth, which would exhibit low height due to herbivory but a substantially developed root system. Through this de- fense mechanism, plants are capable of storing resources in the roots during the presence of a negative environmental pressure; when this pressure is removed, individuals can utilize these resources for the development of aboveground biomass, resulting in a faster growth rate in a relatively short amount of time (Van Bloem et al. 2006). It is important to consider that this study period was short, and we would need to monitor the population for a longer period of time to better understand how the higo chumbo responds to the absence of these invasive mammals in terms of growth. Climatic variability in the Caribbean is high and it can also impact how plants grow and change on a temporal scale, so this factor should also be considered. Therefore, we could expect the recovery of the higo chumbo on Desecheo Island to fluctuate over several years, especially since this is a species that lives for decades.

Other factors have also likely influenced the higo chumbo population on Desecheo. Hurricane Hortense (1996) and Hurricane Georges (1998) likely resulted in severe damage to individuals of $H$. portoricensis, contributing to the major population decrease observed from 1994 to 1999 (Fig. 5). While this species evolved in the presence of such stochastic events, subsequent regrowth would have been inhibited by herbivory. In the long term, recovery of $H$. portoricensis on Desecheo Island may be influenced by climate change, for example, through increased storm frequency, recruitment influenced by changes in microclimatic conditions (Santiago-Vélez 2000, Rojas-Sandoval \& Meléndez-Ackerman 2009a), and increased rainfall events affecting flower development (Rojas-Sandoval \& Meléndez-Ackerman 2009a).

Other potential threats to the species include fruit and seed predation by black rats Rattus rattus and green iguana Iguana iguana, diseases from pathogens like fungi, viruses, or bacteria, and the establishment of invasive grasses following macaque and goat removal (Breckon \& Kolterman 1994, RojasSandoval and Meléndez-Ackerman 2009b). Black rats were successfully eradicated from the island in 2016. Although there was no genetic variability in this species 20 yr ago, Desecheo Island could still be important for metapopulation structure of the higo chumbo in the future. Post-eradication recovery of this species documented in this study demonstrates the conservation benefit of herbivory removal hypothesized in the USFWS Recovery Plan for $H$. portoricensis (USFWS 1996). Because of the relatively small and discrete populations across Desecheo, Mona, and Monito islands and the generally poor recruitment rates for the species, we recommend 
additional recovery actions including promoting the establishment of new sites on Desecheo through translocation, ex situ conservation, and seed banking. Long-term monitoring is also recommended to inform future management decisions for the species. Comparable studies with the Mona population would also be valuable, including understanding the historic and current pollination mechanisms, to understand how well the species can recover in situ. Monitoring changes in, and incursions of, other invasive species threats including grasses, insect pests, and plant pathogens is also recommended to safeguard the population on Desecheo Island, along with the implementation of a biosecurity plan.

Acknowledgements. This study was supported by the United States Fish and Wildlife Service (USFWS), funds from the Neotropical Migratory Bird Conservation Act, and private donors to Island Conservation. The USFWS Caribbean Islands National Wildlife Refuge Complex (Cabo Rojo, Puerto Rico) provided island access to research teams, and significant personnel support for field site visits. Logistical support was also provided by the Maritime Unit of the Law Enforcement Unit from the Department of Natural and Environmental Resources of Puerto Rico (DNER-PR). Thanks to José Sustache for providing insightful comments and suggestions that significantly improved this manuscript, and to J.P. Zegarra for assisting with photo editing. We express our deepest gratitude to the field assistants from Island Conservation, the Coastal Conservation Action Lab (UCSC), the USFWS, the Ornithological Society of Puerto Rico (SOPI), USFWS law enforcement and the Cuerpo de Vigilantes (DNER-PR); their dedication and commitment made these conservation efforts possible. The findings and conclusions in this article are those of the authors and do not necessarily represent the views of the US Fish and Wildlife Service. Use of trade names in this article does not imply endorsement by the United States government.

\section{LITERATURE CITED}

Anadón-Irizarry V, Wege DC, Upgren A, Young R and others (2012) Sites for priority biodiversity conservation in the Caribbean Islands Biodiversity Hotspot. J Threat Taxa 4: 2806-2844

Anderson EF (2001) The Cactus family. Timber Press, Portland, OR

Aslan CE, Zavaleta ES, Croll D, Tershy B (2012) Effects of native and non-native vertebrate mutualists on plants. Conserv Biol 26:778-789

Auld BA, Medd RW (1992) Weeds: an illustrated botanical guide to the weeds of Australia. Inkata Press, Melbourne

Bellingham PJ, Towns DR, Cameron EK, Davis JJ, Wardle DA, Wilmhurst JM, Mulder CPH (2010) New Zealand island restoration: seabirds, predators, and the importance of history. N Z J Ecol 34:115-136

Breckon GJ (2000) Revision of the flora of Desecheo Island, Puerto Rico. Caribb J Sci 33:177-209

Breckon GJ, Kolterman DA (1994) Harrisia portoricensis Britton [Cactaceae]. US Department of the Interior, Fish and Wildlife Service, University of Puerto Rico, Mayaguez Breckon GJ, Kolterman DA, Santiago-Vélez V, LópezArroyo F (1998) Flora of Monito Island, Puerto Rico: observations and new records. Caribb J Sci 34:132-136

Casas A, Valiente-Banuet A, Caballero J (2002) Evolutionary trends in columnar cacti under domestication in south-central Mexico. In: Fleming TH, Valiente-Banuet R (eds) Columnar cacti and their mutualists. University of Arizona Press, Tucson, p 137-163

* Dun EA, Ferguson BJ, Beveridge CA (2006) Apical dominance and shoot branching: Divergent opinions or divergent mechanisms? Plant Physiol 142:812-819

Evans MA (1989) Ecology and removal of introduced rhesus monkeys: Desecheo Island National Wildlife Refuge, Puerto Rico. P R Health Sci J 8:139-156 + errata

Fleming TH, Valiente-Banuet A (eds) (2002) Columnar cacti and their mutualists. University of Arizona Press, Tucson

* Godínez-Álvarez HT, Valverde T, Ortega-Baes P (2003) Demographic trends in the Cactaceae. Bot Rev 69:173-203

*Hamann O (1993) On vegetation recovery, goats and giant tortoises on Pinta Island, Galápagos, Ecuador. Biodivers Conserv 2:138-151

Hamann O (2001) Demographic studies of three indigenous stand-forming plant taxa (Scalesia, Opuntia, and Bursera) in the Galápagos Islands, Ecuador. Biodivers Conserv 10:223-250

Hanson CC, Hall TJ, DeNicola AJ, Silander S, Keitt BS, Campbell KJ (in press) Rhesus macaque eradication to restore the ecological integrity of Desecheo National Wildlife Refuge, Puerto Rico. In: Veitch CR, Clout MN, Genovesi P, Martin A, Russell J, West C (eds) Island invasives: scaling up to meet the challenge, IUCN, Gland

Island Conservation (2009) Scoping trip to Desecheo Island, Puerto Rico, to evaluate feasibility of rodent eradication, and implement baseline biological surveys: February 12-26, 2009. Internal Report, 1-11. Island Conservation, Santa Cruz, CA

Jones HP, Holmes ND, Butchart SHM, Tershy BR and others (2016) Invasive mammal eradication on islands results in substantial conservation gains. Proc Natl Acad Sci USA 113:4033-4038

Liogier HA (1994) Descriptive flora of Puerto Rico and adjacent islands, Vol 3. Editorial de la Universidad de Puerto Rico, Río Piedras

*Meléndez-Ackerman EJ, Cortés C, Sustache J, Aragón S, Morales-Vargas M, García-Bermúdez M, Fernández DS (2008) Diet of feral goats in Mona Island Reserve. Caribb J Sci 44:199-205

Morrison JA, Menzel EW (1972) Adaptations of a freeranging rhesus monkey group to division and transplantation. Wildl Monogr 31:1-78

Myers N, Mittermeier RA, Mittermeier CG, da Fonseca GAB, Kent J (2000) Biodiversity hotspots for conservation priorities. Nature 403:853-858

Noble R, Meier A (1989) Status of boobies, Sula sula and Sula leucogaster, on Desecheo Island, Puerto Rico. US Fish and Wildlife Service, Boquerón

* Ortega-Baes P, Godínez-Álvarez HT (2006) Global diversity and conservation priorities in the Cactaceae. Biodivers Conserv 15:817-827

Rojas-Sandoval J (2010) Identification and evaluation of vulnerability factors affecting the Caribbean cactus species Harrisia portoricensis. PhD dissertation, University of Puerto Rico, San Juan

Rojas-Sandoval J, Meléndez-Ackerman E (2009a) Factors 
affecting seed germination and seedling establishment of Harrisia portoricensis (Cactaceae) in Mona Island. Poster on project funded by National Science Foundation, Center for Applied Tropical Ecology and Conservation, presented at the External Scientific Advisory Committee (ESAC) conference, November 2009, University of Puerto Rico, Río Piedras Campus, San Juan

Rojas-Sandoval J, Meléndez-Ackerman E (2009b) Avances sobre la historia natural de Harrisia portoricensis, un cactus endemico y amenazado en Isla de Mona. Boletín de la Sociedad Latinoamericana y del Caribe de Cactaceas y otras Suculentas 6:27-29

Rojas-Sandoval J, Meléndez-Ackerman EJ, Fumero-Cabán J, García-Bermúdez MA and others (2014) Effects of hurricane disturbance and feral goat herbivory on the structure of a Caribbean dry forest. J Veg Sci 25:1069-1077

Santiago-Vélez VL (2000) Population genetics of Harrisia portoricensis Britton (Cactaceae), a rare island endemic. MSc thesis, University of Puerto Rico, Mayaguez

Schweizer D, Jones HP, Holmes ND (2016) Literature review and meta-analysis of vegetation responses to goat and European rabbit eradications on islands. Pac Sci 70:55-71

Seiders VM, Briggs RP, Glover L (1972) Geology of Isla Desecheo, Puerto Rico, with notes on the Great Southern Puerto Rico Fault Zone and Quaternary stillstands of the sea. US Geol Surv Prof Pap 739:1-22

Sengupta A, McConkey KR, Radhakrishna S (2014) Seed dispersal by rhesus macaques Macaca mulatta in northern India. Am J Primatol 76:1175-1184

Shiels AB, Flores CA, Khamsing A, Krushelnycky PD, Mosher SM, Drake DR (2013) Dietary niche differentiation among three species of invasive rodents (Rattus rattus, $R$. exulans, Mus musculus). Biol Invasions 15:1037-1048

Simberloff D, Von Holle B (1999) Positive interactions of nonindigenous species: Invasional meltdown? Biol Invasions 1:21-32

Struthers P (1927) Notes on the bird-life of Mona and

Editorial responsibility: Hans Juergen Boehmer,

Suva, Fiji Islands
Desecheo Islands. Auk 44:539-544

Sussman RW, Tattersall I (1981) Behavior and ecology of Macaca fascicularis in Mauritius: a preliminary study. Primates 22:192-205

Tershy BR, Shen KW, Newton KM, Holmes ND, Croll DA (2015) The importance of islands for the protection of biological and linguistic diversity. Bioscience 65:592-597

*Towns DR, Atkinson IAE, Daugherty CH (2006) Have the harmful effects of introduced rats on islands been exaggerated? Biol Invasions 8:863-891

USFWS (US Fish and Wildlife Service) (1996) Harrisia portoricensis (higo chumbo) recovery plan. US Fish and Wildlife Service, Atlanta

USFWS (2010) Higo chumbo (Harrisia portoricensis) 5-year review: summary and evaluation. US Fish and Wildlife Service Southeast Region, Caribbean Ecological Services Field Office, Boquerón

USFWS (2011) Desecheo Island National Wildlife Refuge: rat eradication to promote ecosystem restoration: final environmental assessment. Caribbean Islands National Wildlife Refuge Complex, Boquerón

*Van Bloem S, Lugo A, Murphy P (2006) Structural response of Caribbean dry forests to hurricane winds: a case study from Guánica Forest, Puerto Rico. J Biogeogr 33:517-523

Walter KS, Gillett HJ (eds) (1998) 1997 IUCN Red List of Threatened plants. IUCN, Gland

Wege DC, Ryan D, Varty N, Anadón-Irizarry V, Pérez-Leroux A (2010) Ecosystem profile: the Caribbean islands biodiversity hotspot. Critical Ecosystem Partnership Fund, Washington, DC. www.cepf.net/Documents/Finaldraft_ Caribbean_EP.pdf

Woodbury RC, Maretonell LF, García-Tudurí JC (1971) The flora of Desecheo Island, Puerto Rico. J Agric Univ P R 55:478-505

Zimmermann H, Pérez-Sandi M (2006) The consequences of introducing the cactus moth Cactoblastis cactorum to the Caribbean and beyond. Boletín Informativo, México, DF

Submitted: December 6, 2016; Accepted: September 9, 2017 Proofs received from author(s): November 13, 2017 